\title{
Financial Statement Comparability and Information Risk
}

\author{
Liya Hou \\ St. Cloud State University
}

This study extends the prior research on comparability benefits and examines the relation between financial statement comparability and information risk. I expect that higher accounting comparability of financial statements enhances the utility of accounting data for investors by helping them to identify the similarities and differences between economic events and thus decrease the information risk of firms with higher accounting comparability. Consistent with my predictions, I find that firms with higher financial statement comparability have lower information risk and this effect is more pronounced for firms with high earnings volatility. The findings suggest that accounting comparability facilitates the users of financial statements to better understand firms' accounting data and therefore increases the usefulness of financial statement information and helps investors make better judgement on firms' performances and, as a result, make better investment decisions.

Keywords: financial statement comparability, information risk, comparability benefit

\section{INTRODUCTION}

Financial statement comparability (or accounting comparability) is defined by Financial Accounting Standards Board (FASB, 2010) as "the quality of information that enables users to identify similarities in and differences between two sets of economic phenomena" and has been emphasized by Generally Accepted Accounting Principles (GAAP). According to FASB, "Investors, companies, auditors, and other participants in the U.S. financial reporting system benefit from the increased comparability that can result from the closer alignment of standards used internationally." Due to the importance of accounting comparability, this study extends the prior research on comparability benefits (e.g., DeFond et al., 2011; Tan et al., 2011; Petaibanlue et al., 2015) and explores the linkage between financial statement comparability and information risk. Specifically, I examine whether firms with higher financial statement comparability have lower information risk, and whether the negative association (if exists) varies with firms' earnings volatility.

To investigate my first research question, I measure accruals quality as a proxy for information risk (Francis et al., 2005; Kravet and Shevlin, 2010) by regressing total current accruals on lag, current, and lead cash flows, and on change in revenues and $P P E$ to calculate the 5-year rolling standard deviation of residuals from the regression. Therefore, the larger standard deviation of residuals indicates poorer accruals quality and thus higher information risk. Next, I follow De Franco et al. (2011) to create a firm-year measure of financial statement comparability: first, I regress the quarterly net income before extraordinary items scaled by the beginning-of-period market value of equity on the stock price returns during the quarter to obtain the estimated parameters $\widehat{a_{1}}$ and $\widehat{a_{2}}$ proxy for the accounting system for firm $A$ and $B$ by using the 
16 previous quarters of data; second, I use the estimated parameters from the first step (that is, firm $A$ 's and firm $B$ 's accounting system) to estimate the earnings for firm $A$ and $B$ respectively based on the return for firm $A$; third, financial statement comparability between firm $A$ and $B$ is defined as the negative value of the average absolute difference between the predicted earnings for firm $A$ and $B$ obtained from the second step, and larger values indicate greater financial statement comparability (De Franco et al., 2011); finally, the two firm-year measures of financial statement comparability are created based on the average financial statement comparability for each firm $A$ - firm $B$ pair within the same two-digit SIC industry classification from the top-4 firms $B$ and top-10 firms $B$ respectively with the highest financial statement comparability of firm $A$ during period $t$. Then I regress information risk on financial statement comparability, firm characteristics controls, industry fixed effects, and year fixed effects to test my first hypothesis. To examine my second research question, I measure earnings volatility based on the standard deviation of net income before extraordinary items scaled by average assets over the rolling prior 10-year period. Then I regress information risk on financial statement comparability, earnings volatility, their interaction variable, firm characteristics controls, industry fixed effects and year fixed effects to test my second hypothesis. Consistent with my predictions, I find that firms with higher financial statement comparability have lower information risk and this effect is more pronounced for firms with higher earnings volatility.

This study contributes to both of the financial statement comparability literature and information risk literature by showing that financial statement comparability reduces the information risk, especially for firms with higher earnings volatility. This study implies that accounting comparability increases the usefulness of financial statement information and helps investors judge firms' performances and thus make better investment decisions.

My paper is structured as follows: Section 2 provides general background on financial statement comparability and my hypotheses; Section 3 discusses the research design; Section 4 presents the empirical results, and Section 5 concludes.

\section{LITERATURE REVIEW AND HYPOTHESES}

\section{Literature Review of Accounting Comparability}

Financial statement comparability (or accounting comparability) is of interest and important to regulators, researchers, and investors. From regulators' perspectives, the importance of financial statement comparability has been underscored by GAAP. For instance, the Statement of Financial Accounting Concepts (1980) regarding Qualitative Characteristics of Accounting Information states that "investing and lending decisions essentially involve evaluations of alternative opportunities, and they cannot be made rationally if comparative information is not available" (FASB, 1980). Besides, the Statement of Financial Accounting Concepts (2010) regarding Conceptual Framework for Financial Reporting states that "relevant and faithfully represented information is most useful if it can be readily compared with similar information reported by other entities and by the same entity in other periods" (FASB, 2010). From researchers' perspectives, prior literature provides various evidence on comparability benefits.

De Franco et al. (2011) conceptually define the accounting system "as a mapping from economic events to financial statements" and define financial statement comparability as "two firms have comparable accounting systems if, for a given set of economic events, they produce similar financial statements." They create both of firm-pair-year measure and firm-year measure of financial statement comparability and find that financial statement comparability is positively associated with analyst coverage and analyst forecast accuracy (De Franco et al., 2011).

Tan et al. (2011) apply a similar concept - accounting harmonization - and they find that mandatory International Financial Reporting Standards (IFRS) adoption increases foreign analysts following, particularly those who are located in a country that adopts IFRS at the same time as the firm's country and those with prior IFRS experience. They also find that IFRS adoption improves foreign analysts' forecast accuracy. Their evidence implies that comparability benefits, brought by accounting harmonization, increase the usefulness of accounting data (Tan et al., 2011). Related to the topic of mandatory IFRS adoption, DeFond et al. (2011) investigate changes in foreign mutual fund investment in firms after 
mandatory IFRS adoption in the European Union in 2005 and find that foreign mutual fund ownership increases when mandatory IFRS adoption leads to improved comparability.

By deriving a firm-specific Expected Comparability Benefit (ECB) score as the number of industrysize matched foreign peers newly adopting IFRS, Petaibanlue et al. (2015) show that improvements in analyst forecast accuracy after the mandatory adoption of IFRS across Europe are positively and significantly related to their ECB score. They also show that the comparability benefits reflected in forecast accuracy differ according to the pre-IFRS adoption GAAP of the firm and its new peers (Petaibanlue et al., 2015).

Zhang (2018) uses audit fees and audit delay to measure audit effort and find that accounting comparability is negatively associated with audit effort and the likelihood of audit opinion errors. His study provides evidence that accounting comparability increases the usefulness of accounting information for external audits (Zhang, 2018).

\section{Hypotheses}

I extend the prior literature that focuses on the accounting comparability benefits to financial analysts and auditors and study the benefits of financial statement comparability to investors in terms of the reduction in information risk. Specifically, I expect that higher accounting comparability of financial statements enhances the utility of accounting data for investors by helping them to identify the similarities and differences between economic events and thus decrease the information risk of these firms with higher accounting comparability.

In addition, it is more difficult for financial statement users to understand firms' accounting information if the firms have higher earnings volatility, which makes the performances of these firms more unpredictable. As a result, high earnings volatility of the firms complicates the decision-making processes of the users of these firms' financial statements. I hypothesize that the benefits of financial statement comparability are more pronounced for firms with high earnings volatility by reducing information risk for investors.

Based on the above discussions, I propose the following hypotheses, in alternative form:

H1: Financial statement comparability is negatively associated with information risk.

H2: The negative association between financial statement comparability and information risk is more pronounced for firms with high earnings volatility.

\section{RESEARCH DESIGN}

\section{Measure of Information Risk}

Following Francis et al. (2005), I measure accruals quality as a proxy for information risk. Specifically, accruals quality is based on the Dechow-Dichev model (Dechow and Dichev, 2002) with the key variables from the modified Jones model (Jones, 1991) and is calculated as the 5-year rolling standard deviation of residuals (Francis et al., 2005) from model (1) as below:

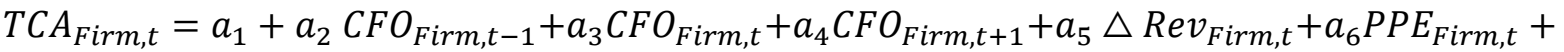

$$
\begin{aligned}
& v_{\text {Firm, } t}
\end{aligned}
$$

where TCA is total current accruals, calculated as change in current assets between year $t-1$ and year $t$ minus change in current liabilities between year $t-1$ and year $t$ minus change in cash between year $t-1$ and year $t$ and plus change in debt in current liabilities between year $t-1$ and year $t$. $C F O$ is cash flow from operations, calculated as net income before extraordinary items minus total accruals $T A$, which is calculated as total current accruals minus depreciation and amortization expense in year $t . \triangle R e v$ is change in revenues between year $t-1$ and year $t$ and $P P E$ is gross value of PPE in year $t$. 
Following Francis et al. (2005) and Kravet and Shevlin (2010), I estimate model (1) for each of Fama and French's (1997) 48 industry groups with at least 20 firms in year $t$. The extreme values of the distribution are winsorized to the 1 and 99 percentiles. Then I calculate the standard deviation of residuals from annual cross-sectional estimations of model (1) over years $t-4$ through $t$ as accruals quality, a proxy for information risk (Francis et al., 2005; Kravet and Shevlin, 2010). Specifically, higher information risk is reflected by poorer accruals quality, which is indicated by larger standard deviation of residuals from model (1).

\section{Measure of Financial Statement Comparability}

Following De Franco et al. (2011), I conduct the following procedures to measure financial statement comparability.

First, I estimate the following model (2) using the 16 previous quarters of data:

Earnings $_{\text {Firm }, t}=a_{1}+a_{2}$ Return $_{\text {Firm }, t}+v_{\text {Firm }, t}$

where Earnings is the quarterly net income before extraordinary items scaled by the beginning-of-period market value of equity. Return is the stock price returns during the quarter. The estimated parameters $\widehat{a_{1}}$ and $\widehat{a_{2}}$ proxy for the accounting system for firm $A$ as $\widehat{a_{1, \text { firm }} A}$ and $\widehat{a_{2, f \text { frm }} A}$ by using the earnings and return of firm $\mathrm{A}$, and the same procedure is repeated for firm $B$ to get $\widehat{a_{1, \text { firm } B}}$ and $\widehat{a_{2, \text { firm }} B}$ by using the earnings and return of firm $B$.

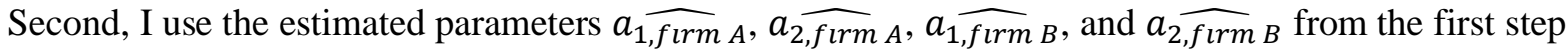
to estimate the following model (3) and (4) based on the return for firm $A$ to predict the earnings for firm $A$ and $B$ respectively:

$$
\begin{aligned}
& \text { Earnıngs } \widehat{\text { estımated,fırm } A}=a_{1, \widehat{\text { flrm }} A}+a_{2, \widehat{f \text { flrm }} A} \times \text { Return }_{\text {firm } A, t} \\
& \text { Earnıngs } \widehat{\text { estımated,fırm } B}=a_{1, \widehat{\text { flrm }} B}+a_{2, \widehat{\text { flrm } B}} \times \text { Return }_{\text {firm } A, t}
\end{aligned}
$$

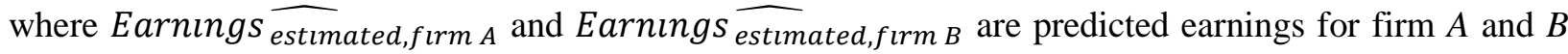
given firm $A$ 's and firm $B$ 's accounting system and firm $A$ 's return.

Third, according to De Franco et al. (2011), financial statement comparability between firm $A$ and $B$ is defined as the negative value of the average absolute difference between the predicted earnings for firm $A$ and $B$ obtained from the second step. Therefore, greater financial statement comparability is reflected by the larger values of FSComp $_{\text {Firm } A, B, t}$.

FSComp $_{\text {Firm } A, B, t}=-\frac{1}{16} \times \sum_{t-15}^{t} \mid$ Earnings $_{\text {estımated,firm } A}-$ Earnings $_{\text {estımated,firm } B} \mid$

Following De Franco et al. (2011), I first estimate financial statement comparability for each firm $A-$ firm $B$ pair within the same two-digit SIC industry classification and then create a firm-year measure of

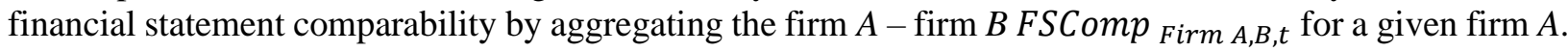
Specifically, I rank all the values of $F_{S C o m p}$ Firm $A, B, t$ for each firm $A$ from the highest to lowest. FSCompl is the average FSComp Firm $A, B, t_{\text {of }}$ of the four firms $B$ with the highest financial statement comparability of firm $A$ during period $t$, and $F S C o m p 2$ is the average $F S C o m p p_{F i r m ~ A, B, t}$ of the ten firms $B$ with the highest financial statement comparability of firm $A$ during period $t$. 


\section{Tests of Hypotheses}

To test Hypothesis 1, I estimate models (6) and (7) to regress information risk $I R_{F i r m, t}$ on financial statement comparability (FSComp 1 and FSComp2 respectively) and firm characteristics controls. I further include industry fixed effects and year fixed effects in the regressions as follows:

$I R_{\text {Firm }, t}=b_{1}+b_{2}$ FSComp $1_{\text {Firm }, t-1}+$ Firm Characteristics Controls + Industry Fixed Effect + Year Fixed Effect $+v_{\text {Firm }, t}$

$I R_{\text {Firm }, t}=b_{1}+b_{2}$ FSComp $2_{\text {Firm }, t-1}+$ Firm Characteristics Controls + Industry Fixed Effect + Year Fixed Effect $+v_{\text {Firm }, t}$

If the coefficient $b_{2}$ on FSComp $1_{\text {Firm }, t-1}$ in model (6) or FSComp $2_{F i r m, t-1}$ in model (7) is negative and statistically significant, then it suggests that financial statement comparability is negatively associated with information risk.

To test Hypothesis 2, I first create a variable $\mathrm{EVol}_{\text {Firm, }}$ as a proxy for earnings volatility (De Franco et al., 2011), measured as the standard deviation of net income before extraordinary items scaled by average assets over the rolling prior 10-year period and require at least 5 observations of net income before extraordinary items to calculate the $E V o l_{F i r m, t}$. I then regress information risk on $E V o l_{F i r m, t}$, financial statement comparability (FSComp1 or FSComp2 respectively), the interaction variable of FSComp1× $E V o l$ or FSComp $2 \times E V o l$, and firm characteristics controls. Again, I further include industry fixed effects and year fixed effects in models (8) and (9) as follows:

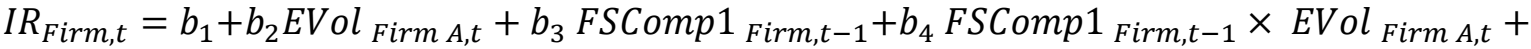

$$
\begin{aligned}
& \text { Firm Characteristics Controls }+ \text { Industry Fixed Effect }+ \text { Year Fixed Effect }+v_{\text {Firm }, t}
\end{aligned}
$$

If the coefficient $b_{4}$ on FSComp $1_{\text {Firm,t-1 }} \times E V o l_{\text {Firm A,t }}$ in model (8) or FSComp $2_{\text {Firm, },-1} \times$ $E V o l_{\text {Firm A,t }}$ in model (9) is negative and statistically significant, then it suggests that the negative association between financial statement comparability and information risk is more pronounced for firms with high earnings volatility.

\section{Control Variables}

Following the prior literature (e.g., Francis et al., 2005), I include in models (6) to (9) a set of firm characteristics control variables: (1) firm size, Size, measured as the nature log of total assets in year $t ;(2)$ market-to-book ratio, $M T B$, measured as the ratio of market value equity to book value equity; (3) firm leverage, Leverage, measured as the interest-bearing debt scaled by the total assets in year $t$; (4) firm's return on assets in year $t, R O A$, measured as net income before extraordinary items divided by the beginning-of-year total assets; (5) firm's length of operating cycle, $O C$, measured as the sum of days accounts receivable and days inventory; (6) Sales growth, SaleGrowth, measured as year-to-year percentage change in sales; and (7) sales volatility, SaleVolatility, measured as the standard deviation of sales revenues.

\section{EMPIRICAL RESULTS}

Table 1 displays the sample selection procedure. I first obtain accounting data from Standard \& Poor's Compustat database and obtain stock returns from CSRP database from 1981 to 2001. I then discard observations with insufficient data to compute accruals quality and financial statement comparability. 
Finally, I discard observations with insufficient data to compute other regression variables. The final sample consists of 22,588 firm-year observations.

TABLE 1

SAMPLE CONSTRUCTION

\begin{tabular}{ll}
\hline Selection criteria & $\begin{array}{l}\text { Number of } \\
\text { observations }\end{array}$ \\
\hline Full Compustat yearly database in fiscal years 1981-2001 & 216,441 \\
Discard observations with insufficient data to compute accruals quality & 77,434 \\
Discard observations with insufficient data to compute accounting comparability & 32,610 \\
Discard observations with insufficient data to compute other regression variables & 22,588 \\
\hline
\end{tabular}

Table 2 shows the description of the key variables used in the empirical tests.

TABLE 2

\section{DESCRIPTION OF KEY VARIABLES}

\begin{tabular}{|c|c|}
\hline Variable & Definition \\
\hline InformationRisk & $\begin{array}{l}\text { Information risk, measured by accruals quality and calculated as the 5-year } \\
\text { rolling standard deviation of residuals from the regression of total current } \\
\text { accruals on lag, current, and lead cash flows, and on change in revenues and } \\
P P E \text {. }\end{array}$ \\
\hline FSComp & $\begin{array}{l}\text { Financial statement comparability between firm } A \text { and } B \text {, defined as the } \\
\text { negative value of the average absolute difference between the predicted } \\
\text { earnings for firm } A \text { and } B \text {. }\end{array}$ \\
\hline FSCompl & $\begin{array}{l}\text { The first firm-year measure of financial statement comparability, which is the } \\
\text { average FSComp Firm } A, B, t \text { of the four firms } B \text { with the highest financial } \\
\text { statement comparability of firm } A \text { during period } t \text {. }\end{array}$ \\
\hline FSComp 2 & $\begin{array}{l}\text { The second firm-year measure of financial statement comparability, which is } \\
\text { the average } F S \operatorname{Comp} p_{\text {Firm } A, B, t} \text { of the ten firms } B \text { with the highest financial } \\
\text { statement comparability of firm } A \text { during period } t \text {. }\end{array}$ \\
\hline EVol & $\begin{array}{l}\text { Earnings volatility, measured as the standard deviation of net income before } \\
\text { extraordinary items scaled by average assets over the rolling prior } 10 \text {-year } \\
\text { period. }\end{array}$ \\
\hline Size & Firm size, measured as the nature log of total assets in year $t$. \\
\hline$M T B$ & $\begin{array}{l}\text { Market-to-book ratio, measured as the ratio of market value equity to book } \\
\text { value equity. }\end{array}$ \\
\hline$L E V$ & $\begin{array}{l}\text { Firm leverage, measured as the interest-bearing debt scaled by the total assets } \\
\text { in year } t \text {. }\end{array}$ \\
\hline
\end{tabular}




\begin{tabular}{ll}
\hline$R O A$ & $\begin{array}{l}\text { Firm's return on assets in year } t \text {, measured as net income before extraordinary } \\
\text { items divided by beginning of year total assets. }\end{array}$ \\
LC & $\begin{array}{l}\text { Length of operating cycle, measured as the sum of days accounts receivable } \\
\text { and days inventory. }\end{array}$ \\
SaleGrowth & Sales growth, measured as year-to-year percentage change in sales. \\
SaleVolatility & Sales volatility, measured as the standard deviation of sales revenues.
\end{tabular}

Table 3 Panel A reports summary statistics for the sample, and Panel B shows pairwise correlations.

TABLE 3

\section{DESCRIPTIVE STATISTICS}

Panel A: Summary Statistics

\begin{tabular}{lllllll}
\hline & $\mathrm{N}$ & Mean & Std. Dev. & P25 & Median & P75 \\
\hline InformationRisk & 22,588 & 0.043 & 0.037 & 0.018 & 0.032 & 0.055 \\
FSComp1 & 22,588 & -0.525 & 0.882 & -0.540 & -0.240 & -0.120 \\
FSComp2 & 22,588 & -0.755 & 1.133 & -0.830 & -0.380 & -0.200 \\
Size & 22,588 & 5.667 & 2.120 & 4.067 & 5.639 & 7.273 \\
MTB & 22,588 & 2.231 & 2.796 & 1.056 & 1.586 & 2.540 \\
LEV & 22,588 & 0.264 & 0.173 & 0.134 & 0.254 & 0.369 \\
ROA & 22,588 & 0.017 & 0.137 & 0.007 & 0.040 & 0.072 \\
OC & 22,588 & 140.842 & 83.180 & 83.098 & 124.361 & 178.600 \\
SaleGrowth & 22,588 & 0.102 & 0.287 & -0.019 & 0.064 & 0.167 \\
SaleVolatility & 22,588 & 0.230 & 0.187 & 0.109 & 0.182 & 0.293 \\
EVol & 22,588 & 0.061 & 0.076 & 0.019 & 0.037 & 0.070 \\
\hline
\end{tabular}

Panel B: Pairwise Correlations

\begin{tabular}{|c|c|c|c|c|c|c|c|c|c|c|c|}
\hline & $(1)$ & $(2)$ & (3) & $(4)$ & $(5)$ & $(6)$ & $(7)$ & $(8)$ & (9) & $(10)$ & (11) \\
\hline (1) InformationRisk & - & & & & & & & & & & \\
\hline (2) FSCompl & -0.247 & - & & & & & & & & & \\
\hline (3) FSComp 2 & -0.259 & 0.982 & - & & & & & & & & \\
\hline (4) Size & -0.456 & 0.209 & 0.220 & - & & & & & & & \\
\hline (5) $M T B$ & 0.146 & 0.063 & 0.065 & 0.020 & - & & & & & & \\
\hline (6) $L E V$ & -0.072 & -0.188 & -0.193 & 0.148 & -0.077 & - & & & & & \\
\hline (7) $R O A$ & -0.380 & 0.300 & 0.318 & 0.275 & -0.043 & -0.177 & - & & & & \\
\hline (8) $O C$ & 0.272 & 0.009 & 0.017 & -0.276 & 0.044 & -0.117 & -0.163 & - & & & \\
\hline (9) SalesGrowth & 0.068 & 0.051 & 0.055 & 0.003 & 0.140 & 0.004 & 0.098 & -0.125 & - & & \\
\hline (10) SalesVolatility & 0.375 & -0.166 & -0.178 & -0.367 & 0.026 & -0.016 & -0.111 & -0.011 & 0.038 & - & \\
\hline (11) EVol & 0.582 & -0.184 & -0.195 & -0.420 & 0.193 & -0.066 & -0.405 & 0.212 & 0.117 & 0.360 & - \\
\hline
\end{tabular}

Table 4 presents the effect of financial statement comparability on information risk. The empirical results support my H1. In Table 4, the coefficient $b_{2}$ on FSComp $1_{\text {Firm }, t-1}\left(b_{2}=-0.007, p-\right.$ value $<$ 0.01 in columns I and III) in model (6) or FSComp2 $2_{\text {Firm,t-1 }}\left(b_{2}=-0.006, p-\right.$ value $<0.01$ in 
columns II and IV) in model (7) is negative and statistically significant. Therefore, the results in Table 4 suggest that financial statement comparability is negatively associated with information risk.

\section{TABLE 4}

\section{FINANCIAL STATEMENT COMPARABILITY AND INFORMATION RISK}

\begin{tabular}{|c|c|c|c|c|c|}
\hline Dependent Variable: $I R$ & Prediction & I & II & III & IV \\
\hline FSCompl & - & $\begin{array}{l}-0.007 * * * \\
(-9.46)\end{array}$ & & $\begin{array}{l}-0.007 * * * \\
(-9.41)\end{array}$ & \\
\hline FSComp 2 & - & & $\begin{array}{l}-0.006^{* * *} \\
(-9.97)\end{array}$ & & $\begin{array}{l}-0.006 * * * \\
(-9.97)\end{array}$ \\
\hline Size & & $\begin{array}{l}-0.005^{* * *} \\
(-15.62)\end{array}$ & $\begin{array}{l}-0.005^{* * *} \\
(-15.60)\end{array}$ & $\begin{array}{l}-0.004 * * * \\
(-13.78)\end{array}$ & $\begin{array}{l}-0.004 * * * \\
(-13.66)\end{array}$ \\
\hline$M T B$ & & $\begin{array}{l}0.001 * * * \\
(7.41)\end{array}$ & $\begin{array}{l}0.001 * * * \\
(7.29)\end{array}$ & $\begin{array}{l}0.001 * * * \\
(7.00)\end{array}$ & $\begin{array}{l}0.001 * * * \\
(6.87)\end{array}$ \\
\hline$L E V$ & & $\begin{array}{l}-0.000 \\
(-0.08)\end{array}$ & $\begin{array}{l}-0.001 \\
(-0.28)\end{array}$ & $\begin{array}{l}-0.004 * \\
(-1.66)\end{array}$ & $\begin{array}{l}-0.004 * \\
(-1.86)\end{array}$ \\
\hline$R O A$ & & $\begin{array}{l}-0.058 * * * \\
(-14.05)\end{array}$ & $\begin{array}{l}-0.057 * * * \\
(-13.95)\end{array}$ & $\begin{array}{l}-0.059 * * * \\
(-13.72)\end{array}$ & $\begin{array}{l}-0.058 * * * \\
(-13.62)\end{array}$ \\
\hline$O C$ & & & & $\begin{array}{l}0.000 * * * \\
(5.29)\end{array}$ & $\begin{array}{l}0.000 * * * \\
(5.46)\end{array}$ \\
\hline SalesGrowth & & & & $\begin{array}{l}0.008 * * * \\
(7.23)\end{array}$ & $\begin{array}{l}0.008 * * * \\
(7.27)\end{array}$ \\
\hline SalesVolatility & & & & $\begin{array}{l}0.040 * * * \\
(13.96)\end{array}$ & $\begin{array}{l}0.039 * * * \\
(14.00)\end{array}$ \\
\hline Industry Fixed Effect & & Yes & Yes & Yes & Yes \\
\hline Year Fixed Effect & & Yes & Yes & Yes & Yes \\
\hline No. observations & & 22,588 & 22,588 & 22,588 & 22,588 \\
\hline Adj. R-squared & & 0.448 & 0.450 & 0.477 & 0.480 \\
\hline
\end{tabular}

This table presents the regression results of information risk $I R_{F i r m, t}$ on financial statement comparability (FSCompl in columns I and III, and FSComp2 in columns II and IV respectively) and firm characteristics controls. I further include industry fixed effects and year fixed effects in the regressions. ***,** and * indicate significance at the 0.01 , 0.05 , and 0.10 levels, respectively. $t$-statistics are reported in parentheses below coefficients. Standard errors are twoway clustered by firm and year. 
TABLE 5

FINANCIAL STATEMENT COMPARABILITY AND INFORMATION RISK CONDITIONAL ON EARNINGS VOLATILITY

\begin{tabular}{|c|c|c|c|c|c|}
\hline Dependent Variable: $I R$ & Prediction & $\mathrm{I}$ & II & III & IV \\
\hline FSCompl & - & $\begin{array}{l}-0.004 * * * \\
(-4.85)\end{array}$ & & $\begin{array}{l}-0.004 * * * \\
(-5.05)\end{array}$ & \\
\hline FSComp 2 & - & & $\begin{array}{l}-0.003 * * * \\
(-5.68)\end{array}$ & & $\begin{array}{l}-0.004 * * * \\
(-5.90)\end{array}$ \\
\hline FSComp $1 \times E$ Vol & - & $\begin{array}{l}-0.002 * \\
(-1.84)\end{array}$ & & $\begin{array}{l}-0.002 * * \\
(-2.01)\end{array}$ & \\
\hline FSComp $2 \times E$ Vol & - & & $\begin{array}{l}-0.002 * * \\
(-1.97)\end{array}$ & & $\begin{array}{l}-0.002 * * \\
(-2.17)\end{array}$ \\
\hline Size & & $\begin{array}{l}-0.004 * * * \\
(-13.30)\end{array}$ & $\begin{array}{l}-0.004 * * * \\
(-13.19)\end{array}$ & $\begin{array}{l}-0.003 * * * \\
(-11.89)\end{array}$ & $\begin{array}{l}-0.003 * * * \\
(-11.73)\end{array}$ \\
\hline MTB & & $\begin{array}{l}0.001 * * * \\
(6.48)\end{array}$ & $\begin{array}{l}0.001 * * * \\
(6.40)\end{array}$ & $\begin{array}{l}0.001 * * * \\
(6.23)\end{array}$ & $\begin{array}{l}0.001 * * * \\
(6.14)\end{array}$ \\
\hline$L E V$ & & $\begin{array}{l}-0.001 \\
(-0.28)\end{array}$ & $\begin{array}{l}-0.001 \\
(-0.42)\end{array}$ & $\begin{array}{l}-0.004 \\
(-1.60)\end{array}$ & $\begin{array}{l}-0.004 * \\
(-1.76)\end{array}$ \\
\hline$R O A$ & & $\begin{array}{l}-0.053 * * * \\
(-12.62)\end{array}$ & $\begin{array}{l}-0.053 * * * \\
(-12.56)\end{array}$ & $\begin{array}{l}-0.055^{* * *} \\
(-12.49)\end{array}$ & $\begin{array}{l}-0.055 * * * \\
(-12.44)\end{array}$ \\
\hline$O C$ & & & & $\begin{array}{l}0.000 * * * \\
(5.18)\end{array}$ & $\begin{array}{l}0.000 * * * \\
(5.32)\end{array}$ \\
\hline SalesGrowth & & & & $\begin{array}{l}0.007 * * * \\
(6.71)\end{array}$ & $\begin{array}{l}0.007 * * * \\
(6.78)\end{array}$ \\
\hline SalesVolatility & & & & $\begin{array}{l}0.033 * * * \\
(11.89)\end{array}$ & $\begin{array}{l}0.033 * * * \\
(11.97)\end{array}$ \\
\hline EVol & & $\begin{array}{l}0.015^{* * * *} \\
(9.84)\end{array}$ & $\begin{array}{l}0.014 * * * \\
(9.46)\end{array}$ & $\begin{array}{l}0.012 * * * \\
(8.48)\end{array}$ & $\begin{array}{l}0.011 * * * \\
(8.03)\end{array}$ \\
\hline Industry Fixed Effect & & Yes & Yes & Yes & Yes \\
\hline Year Fixed Effect & & Yes & Yes & Yes & Yes \\
\hline No. observations & & 22,588 & 22,588 & 22,588 & 22,588 \\
\hline Adj. R-squared & & 0.472 & 0.473 & 0.493 & 0.494 \\
\hline
\end{tabular}

This table presents the regression results of information risk $I R_{F i r m, t}$ on financial statement comparability (FSComp 1 in columns I and III, and FSComp 2 in columns II and IV respectively), earnings volatility $E V o l_{F i r m, t}$, the interaction variable of $F S C o m p 1 \times E V o l$ or $F S C o m p 2 \times E V o l$, and firm characteristics controls. I further include industry fixed effects and year fixed effects in the regressions. $* * *, * *$ and $*$ indicate significance at the $0.01,0.05$, and 0.10 levels, respectively. $t$-statistics are reported in parentheses below coefficients. Standard errors are two-way clustered by firm and year.

Table 5 presents the effect of financial statement comparability on information risk conditional on earnings volatility. The empirical results support my $\mathrm{H} 2$. In Table 5 , the coefficient $b_{4}$ on FSComp $1_{\text {Firm }, t-1} \times E V o l_{F i r m ~ A, t}\left(b_{4}=-0.002, p-\right.$ value $<0.10$ in column I, and $b_{4}=$ $-0.002, p-$ value $<0.05$ in column III) in model (8) or FSComp $2_{\text {Firm, } t-1} \times$ EVol $_{\text {Firm A,t }}\left(b_{4}=\right.$ $-0.002, p-$ value $<0.05$ in columns II and IV) in model (9) is negative and statistically significant. 
Therefore, the results in Table 5 suggest that the negative association between financial statement comparability and information risk is more pronounced for firms with high earnings volatility.

\section{CONCLUSION}

This study examines the relation between financial statement comparability and information risk. Specifically, I investigate whether firms with higher financial statement comparability have lower information risk, and whether the negative association (if exists) varies with firms' earnings volatility. Consist with my expectations, firms with higher financial statement comparability have lower information risk, and the negative association between financial statement comparability and information risk is more pronounced for firms with high earnings volatility.

This study contributes to both of the financial statement comparability literature and information risk literature by showing that financial statement comparability reduces the information risk, especially in firms with high earnings volatility. This study makes important contribution and implications regarding the benefits of financial statement comparability. The findings suggest that accounting comparability facilitates the users of financial statements to better understand firms' accounting data and therefore increases the usefulness of financial statement information and helps investors make better judgement on firms' performances and, as a result, make better investment decisions.

\section{REFERENCES}

De Franco, G., Kothari, S.P., \& Verdi, R. (2011). The benefits of financial statement comparability. Journal of Accounting Research, 49(4), 895-931.

Dechow, P., \& Dichev, I. (2002). The quality of accruals and earnings: The role of accrual estimation errors. The Accounting Review, 77(Supplement), 35-59.

DeFond, M., Hu, X., Hung, M., \& Li, S. (2011). The impact of mandatory IFRS adoption on foreign mutual fund ownership: The role of comparability. Journal of Accounting and Economics, 51(3), 240-258.

Financial Accounting Standards Board (FASB). (1980). Statement of Financial Accounting Concepts No. 2: Qualitative Characteristics of Accounting Information. Norwalk, CT: FASB.

Financial Accounting Standards Board (FASB). (2010). Statement of Financial Accounting Concepts No. 8: Conceptual Framework for Financial Reporting. Norwalk, CT: FASB.

Financial Accounting Standards Board (FASB). (n.d.). Retrieved from https://www.fasb.org/cs/Satellite?c=Page\&cid=1176166128698\&d=Touch\&pagename=FASB\%2 FPage\%2FBridgePage

Francis, J., Lafond, R., Olsson, P., \& Schipper, K. (2005). The market pricing of accruals quality. Journal of Accounting and Economics, 39, 295-327.

Jones, J. (1991). Earnings management during import relief investigations. Journal of Accounting Research, 29, 193-228.

Kravet, T., \& Shevlin, T. (2010). Accounting restatements and information risk. Review of Accounting Studies, 15, 264-294.

Petaibanlue, J., Walker, M., \& Lee, E. (2015). When did analyst forecast accuracy benefit from increased cross-border comparability following IFRS adoption in the EU? International Review of Financial Analysis, 42, 278-291.

Tan, H., Wang, S., \& Welker, M. (2011). Analyst following and forecast accuracy after mandated IFRS adoptions. Journal of Accounting Research, 49(5), 1307-1357.

Zhang, J.H. (2018). Accounting comparability, audit effort, and audit outcomes. Contemporary Accounting Research, 35(1), 245-276. 